\title{
Precarious Work in Turkey: A Comparison with EU Member Countries
}

\author{
Onur EMRE \\ Yalova University \\ Department of Management \\ Yalova, Turkey \\ orcid.org/0000-0002-6956-9487 \\ oemre@yalova.edu.tr
}

\author{
Volkan POLAT \\ Yalova University \\ Department of Management \\ Yalova, Turkey \\ orcid.org/0000-0001-6606-2528 \\ vpolat@yalova.edu.tr
}

\author{
Yavuz Selman DUMAN \\ Yalova University \\ Department of Economics \\ Yalova, Turkey \\ orcid.org/0000-0001-6799-5186 \\ ysduman@yalova.edu.tr
}

\begin{abstract}
Precarious work is known for its deleterious effects on workers and it is on the rise especially in developing economies. The purpose of this study is to examine the precarious employment indicators of Turkey in comparison with EU member countries. Using the data from the 5th European Working Conditions Survey; this study uses the type of contracts, income, job insecurity, employability, health and safety risks, autonomy, participation and working hours as indicators of precarious employment and compares figures from a candidate country to the European Union member countries. Results indicate that Turkey ranks low relative to EU members in most dimensions of precariousness, especially in employment contracts and weekly working hours.
\end{abstract}

Keywords: precariousness, job security, autonomy

\section{Introduction}

The requirements of fierce competition in the market and rise of new business models call for flexibility in working relationships, while employees try to maintain a decent work-life balance and gain career advancement opportunities. Along with these, workers also need standardized and well defined employment arrangements to protect themselves from economic fluctuations. Similarly, employers need to be equipped with flexibility to alter their labor requirements, acquire new talents, and dispose the existing labor according to the dynamic demands. 
The weak link in this struggle is the employees. Sometimes their work hours can be reduced to the point that pays very low or they are to work very long hours. They face the risk of losing the work-life balance because of high-demanding jobs and they might even lose their job on arbitrary grounds. It is employees' right to expect a reasonable payment for the effort, to work predictable and decent hours, to get training and education in order to stay competitive, and to have the right to unionize. These rights are gained through struggle after a long painful period. But while the struggle is continuous, the competition and speed of the economy leave some domains unregulated thus making employees vulnerable against these changes. The vulnerability is more prevalent in underdeveloped economies and among sensitive demographics.

This study aims to provide basic facts and figures of precarious employment in European Union and compare the precariousness indicators with figures from Turkey. This paper is among the few that handles precarious employment data for Turkey and conducts a comparative study with European Union members. The year 2017 is the $30^{\text {th }}$ anniversary of Turkey's application for full membership to the European Union and it is consistently regarded as one of the top 20 economies in the world (World Bank, 2017), surpassing many countries within the EU in terms of quantity and quality. Despite her scale, Turkey is still labeled as a developing economy; she has strong ties to Europe and she is constantly transforming in order to align with EU standards.

With this regard, we believe there is merit to compare a candidate country to the other members. European Union brings many labor friendly regulations to the world of work and it is safe to assume that countries within the union are amongst the top countries in terms of pleasantness of working conditions. Thus, it is important to use EU-27 countries as a base of comparison.

\section{Employment Relationships}

Standard employment relationship generally refers to the full-time employment with regular and fixed payments in exchange of a defined work at main employer's premises. This kind of relationship also constitutes the base of legislations, laws, union practices, and labor relationships (Cranford, Vosko, \& Zukewich, 2003). Any form of work that deviates from this definition is regarded as non-standard and/or atypical employment.

Non-standard forms of employment calls for non-standard contracts, they offer limited social rights, bring low job security accompanied with short term employment, and low wages (Lewchuk et al., 2003). Cranford et al., (2003) suggest that precarious employment is a broader term carrying more depth and it is the best concept available to describe deviations from standard employment, simply because it covers both the nonstandard forms and the security dimension.

It was the 1970's and 80's that concepts such as part-time work and outsourcing workers started to emerge as alternative forms of employment. According to Stanford \& Vosko (2004), precarious practices were aimed to break the power of labor unions and intended to give the upper hand to the employer by creating employee groups consisted of women and immigrant workers whom were more vulnerable in contrast to the current employees.

Atypical work brings consequences regarding health. Lewchuk et al., (2003) state that workers in standard forms of employment report better health and well-being 
whereas workers in atypical working arrangements report that they operate on higher stress levels they also report more physical fatigue and pain. Furthermore, according to Benach \& Muntaner (2007), effects of precarious employment are almost hazardous, and extends to family members and dependents.

In precarious forms of work, the amount of control over work is inherently lower than the standard employment relationship. Low control and high effort levels, together, lead to stress reactions and decreased health (Karasek, 1979). Along with a low level of control, workers in precarious work settings, face greater demands from their work and are also subject to different treatment as they have less protection and rights associated with their contracts and peer support. Lim (1996) suggests that receiving support from others in the workplace acts as a shield against dissatisfaction when the job is insecure.

\section{Insecurity}

Studies of job insecurity present similar findings to precariousness. It is possible to study insecurity in two main approaches. According to the view that accepts insecurity as a hindrance stressor, proposes that insecurity entails negative behavioral consequences. Employees are more likely to resort to withdrawal, engage in tardiness, and absenteeism (Staufenbiel \& König, 2010). These behavioral drawbacks are known to result in resistance to change and increased turnover (Fox \& Staw, 1979). Job insecurity is infamous because it decreases well-being, increases depression, anxiety, and several other physical health complaints (Ashford, Lee, \& Bobko, 1989; Orpen, 1993; Roskies \& Louis-Guerin, 1990; Witte, 1999). It is also known that insecurity contributes to burnout (Dekker \&Schaufeli, 1995) and job satisfaction is also higher among workers if they feel their job is secure (Ashford et al., 1989).

Alternatively, the view that job security induces challenge stressors propose different results, stating that job insecurity is likely to reduce withdrawal and increase performance (Staufenbiel \& König, 2010) with the motivation to keep the job and help the organization to facilitate job security. According to Greenhalgh \& Rosenblatt (1984), insecurity rarely leads to increases in effort levels. The challenge and hindrance aspects of stressors are not mutually exclusive and they are known to operate simultaneously (Gilboa, Shirom, Fried, \& Cooper, 2008; Lazarus \& Folkman, 1984). Finally according to Lazarus (1996), "the anticipation of harm can have effects as potent as experiencing the harm itself". With this regard, fear of unemployment can be as devastating as being actually unemployed. In addition, the adverse effects of job insecurity are not limited to work domain. Lim (1996) argues the spillover of insecurity to non-work aspects of life.

\section{Employability}

One aspect of precarious working conditions is the employability. Employability is defined as having the flexibility and possibilities of finding a new job (Berntson, Naswall, \&Sverke, 2010). Employability increases the adaptation of the employees to cope with uncertainties in the labor market and makes them confident against the risk of job losses (Fugate, Kinicki, \& Ashforth, 2004). Employability shields workers against various problems they might face in the workplace as well (Berntson, Sverke, \& Marklund, 2006). However these definitions reflect the perception of the individual and it can be argued that employability is likely to depend on the economic structures, its ability to create jobs, and the formation of the labor market (Berntson et al., 2006). 
Forrier \& Sels (2003) argue that tenure in the company and in the job, is related to employability. Although it can be argued that experience in a job increases specialization, at the same time it may hinder diversification and reduce chances of movement. In addition, employers are less willing to provide training for tenured employees, therefore employees become unable to gain competence to make labor market transitions (Forrier \& Sels, 2003).

\section{Autonomy}

Hackman \& Oldham, (1975) defines autonomy as the degree of independence and discretion over one's work. The discretion and freedom can be used either in the methods used to perform tasks or it can be about the scheduling of work. Autonomy is an essential concept that plays a central role in many organizational theories such as motivation, job design (Hackman \& Oldham, 1976), job demand-control (Karasek, 1979), and work stress (Spector, Dwyer, \& Jex, 1988; Spector \& Fox, 2003). Autonomy enables individuals to better grasp their roles in their job, it integrates them into their work (Morgeson, Delaney-Klinger, \& Hemingway, 2005), motivates employees and stimulates learning (Morgeson, Campion, Garza, \& Campion, 2003), increases wellbeing, self-esteem and creativity thereby increasing worker performance, and quality of relationships at work (Lopes, Lagoa, \& Calapez, 2013).

Low skill works are known to be offering lower levels of autonomy. Lopes et al., (2013) argue that despite the increases in skilled level of workers in the EU, the level of autonomy declined between 1995 and 2010. An important exception of the overall decline would be that workers in Denmark, Finland, the Netherlands, and Sweden experienced an increase in autonomy in the last decades.

\section{Method}

The data used in this study consists of the responses to the $5^{\text {th }}$ European Working Conditions Survey that took place between January 2010 and June 2010. A total of 43816 people were interviewed in the residences of the participants. Data collection included all European Union Members at the time of the survey (EU-27) with the addition of Norway, Croatia, Macedonia, Turkey, Albania, Montenegro and Kosovo. To serve the purposes of this study, only EU 27 countries in 2010 and Turkey were included in the analyses. The final number of responses in the study were 37472 . EWCS was translated into and administered in 32 languages by professional translators and using back-translation procedures (EWCS Technical Report, 2010).

This study partly used the indicators adopted in (Vandenbrande et al., 2012) in reporting the facets of precarious employment and forming summative scales. The type of employment contracts, formal information and training about health and safety regulations, weekly work days along with weekly working hours are presented directly from descriptive analysis of the data. Autonomy is assessed with 3 items from the survey, mainly designed to measure task autonomy $(\alpha=.79)$. A sample item was "Are you able to choose or change your methods of work?" with binary response options. Working time flexibility is assessed with 4 items and a sample item was "Do you work Fixed starting and finishing times?" with binary response options $(\alpha=.81)$. Job insecurity is measured with the item "I might lose my job in 6 months?" with responses ranging from 1 to 5 . Participation is measured with 3 items from the 
questionnaire with a sample question "You are consulted before targets for your work are set" and participants responded using a scale from 1(always) to 5(never) ( $\alpha=.74)$.

\section{Sample}

While respondents from EU-27 countries have a relatively gender balanced participation $(54.5 \%-45.5 \%)$, respondents from Turkey are skewed towards male participants (72.4\%). Mean age of participants are 41 and 37 for participants from EU 27 countries and Turkey respectively. Participant numbers are roughly 1000 for each country except Belgium, Germany, France, Italy, Poland, Slovenia, UK and Turkey which agreed to recruit more participants with special request (EWCS Technical Report, 2010). The amount of participants by country is depicted in Table 1.

Table 1 - Number of Participants in Each Country

\begin{tabular}{|c|c|c|c|}
\hline & & Frequency & Percent \\
\hline \multicolumn{2}{|l|}{ Turkey } & 2100 & 100.0 \\
\hline \multirow{28}{*}{ EU27 } & Belgium & 4001 & 11.3 \\
\hline & Bulgaria & 1014 & 2.9 \\
\hline & Czech Republic & 1000 & 2.8 \\
\hline & Denmark & 1069 & 3.0 \\
\hline & Germany & 2133 & 6.0 \\
\hline & Estonia & 1000 & 2.8 \\
\hline & Greece & 1037 & 2.9 \\
\hline & Spain & 1008 & 2.8 \\
\hline & France & 3046 & 8.6 \\
\hline & Ireland & 1003 & 2.8 \\
\hline & Italy & 1500 & 4.2 \\
\hline & Cyprus & 1000 & 2.8 \\
\hline & Latvia & 1001 & 2.8 \\
\hline & Lithuania & 1004 & 2.8 \\
\hline & Luxembourg & 1000 & 2.8 \\
\hline & Hungary & 1006 & 2.8 \\
\hline & Malta & 1000 & 2.8 \\
\hline & Netherlands & 1017 & 2.9 \\
\hline & Austria & 1003 & 2.8 \\
\hline & Poland & 1500 & 4.2 \\
\hline & Portugal & 1000 & 2.8 \\
\hline & Romania & 1017 & 2.9 \\
\hline & Slovenia & 1404 & 4.0 \\
\hline & Slovakia & 1002 & 2.8 \\
\hline & Finland & 1028 & 2.9 \\
\hline & Sweden & 1004 & 2.8 \\
\hline & United Kingdom & 1575 & 4.5 \\
\hline & Total & 35372 & 100.0 \\
\hline
\end{tabular}

As seen in Table 2, participants from Turkey are mainly employed by private employers $(81.2 \%)$, the ratio is lower for EU-27 member countries $(67.3 \%)$. 
Table 2 - Type of Employer

\begin{tabular}{llll}
\hline EU27 & & Frequency & Percent \\
\hline \multirow{4}{*}{ Turkey } & private sector & 1706 & 81.2 \\
& public sector & 271 & 12.9 \\
& joint private-public organization or company & 15 & .7 \\
& non-for-profit sector, NGO & 3 & .2 \\
& other & 104 & 5.0 \\
\hline \multirow{5}{*}{ EU27 } & private sector & 23817 & 67.3 \\
& public sector & 8716 & 24.6 \\
& joint private-public organization or company & 1457 & 4.1 \\
& non-for-profit sector, NGO & 501 & 1.4 \\
& Other & 602 & 1.7 \\
\cline { 2 - 4 } & & 35372 & 100.0 \\
\hline
\end{tabular}

\section{Results}

\section{Employment Contract}

A considerably lower proportion of employees have more stable labor contracts in Turkey (20.9\%) compared to European Union member countries (65.7\%). Despite the low proportion, this figure is not the alarming one in this comparison. About $40 \%$ of the respondents from Turkey reported that they are working without a contract compared with a ratio of $4.8 \%$ respondents from all over the EU. This data alone is a significant determinant indicating that precarious employment holds a large share among the labor market in Turkey.

Table 3 - Type of Employment Contract

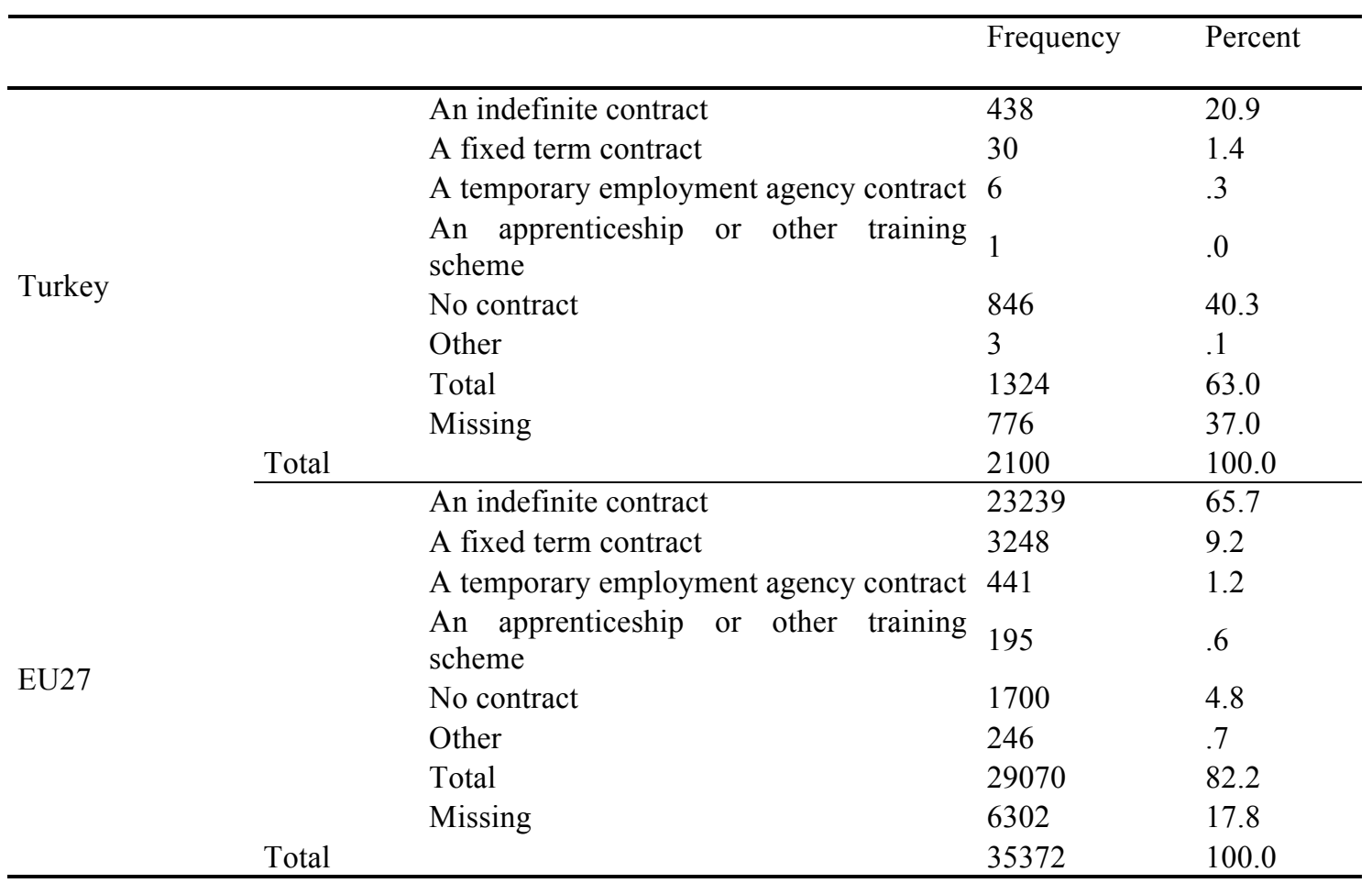

\section{Income}

Mean income of all participants are measured at 1215 Euros. Countries with highest mean income were Luxembourg Denmark and Sweden and the lowest mean 
income were calculated for Latvia, Bulgaria and Romania. Participants from Turkey averaged an income of 477 Euros monthly.

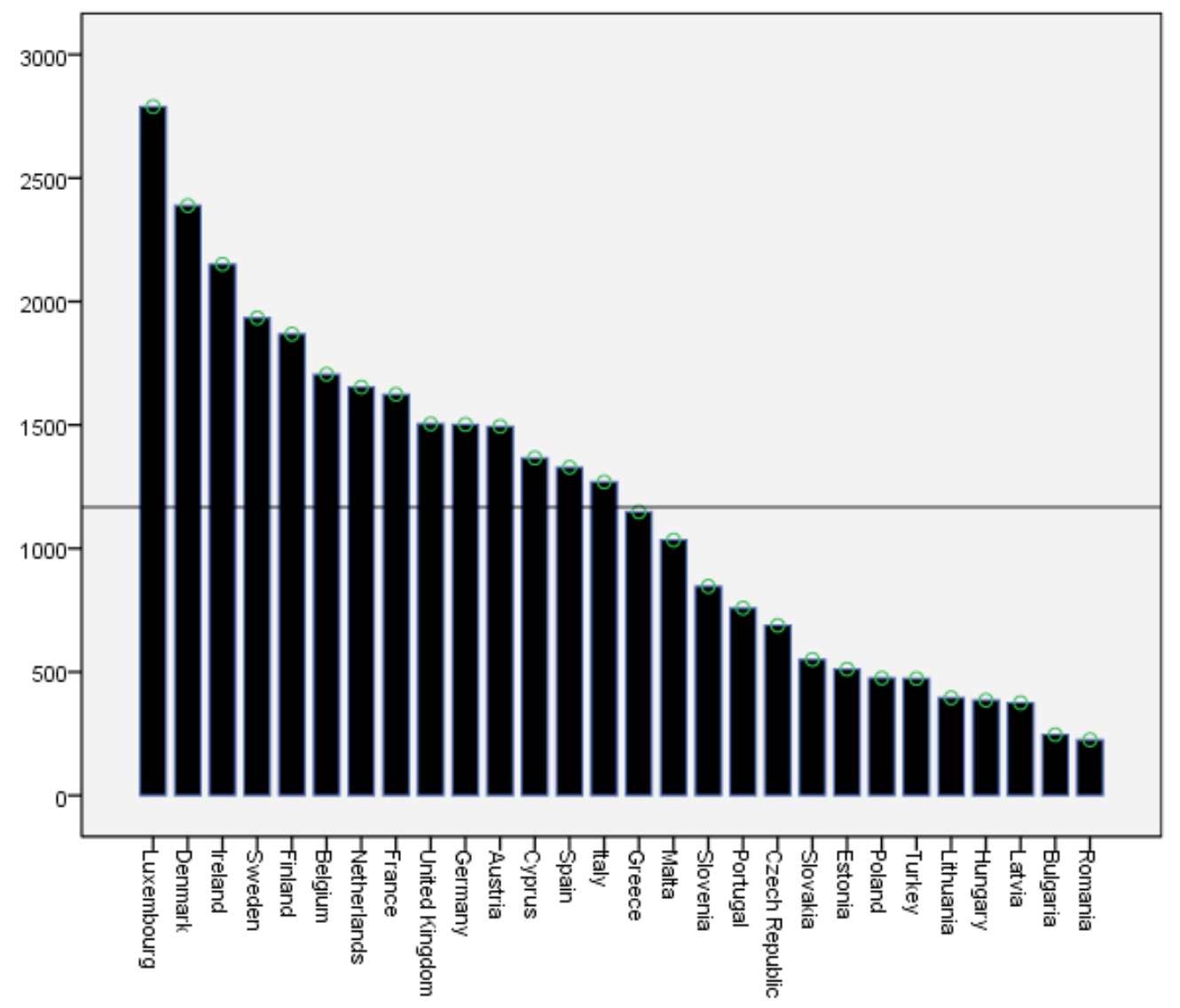

Figure 1-Net monthly earnings from the main paid job? (EURO)

\section{Job Insecurity}

Responses about job insecurity are presented in the bar chart at Figure 2. On the lower end of the job security statistics there are Lithuania, Czech Republic and Estonia while Denmark, Luxembourg and France averaged the highest job security. Turkey is situated in the middle of the spectrum with roughly at mean value of all the countries. 


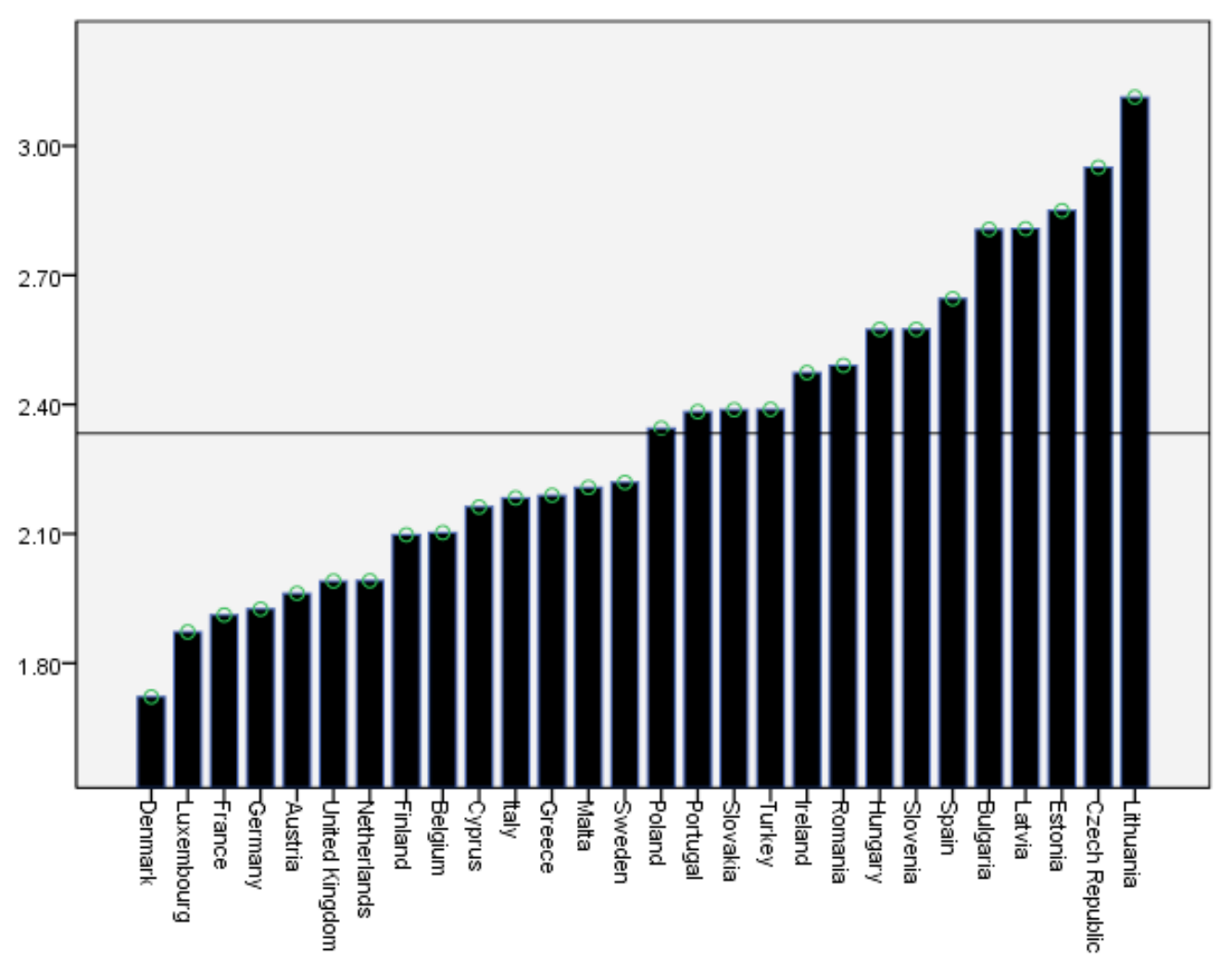

Figure 2 - Mean job insecurity across EU27 countries and Turkey.

\section{Training for Future Employability}

Workers in Greece, Bulgaria, Turkey and Romania reported to have received less training in order to improve their skills; therefore they are assumed to be less employable in the future compared to the other members of the EU. Having received a low the level of training while working for an employer means that the employee will become less employable for other employers, and finally they are less capable of transitioning to other jobs. Figures from Finland, Sweden and Slovenia indicate that the level of training is the highest in these countries. 


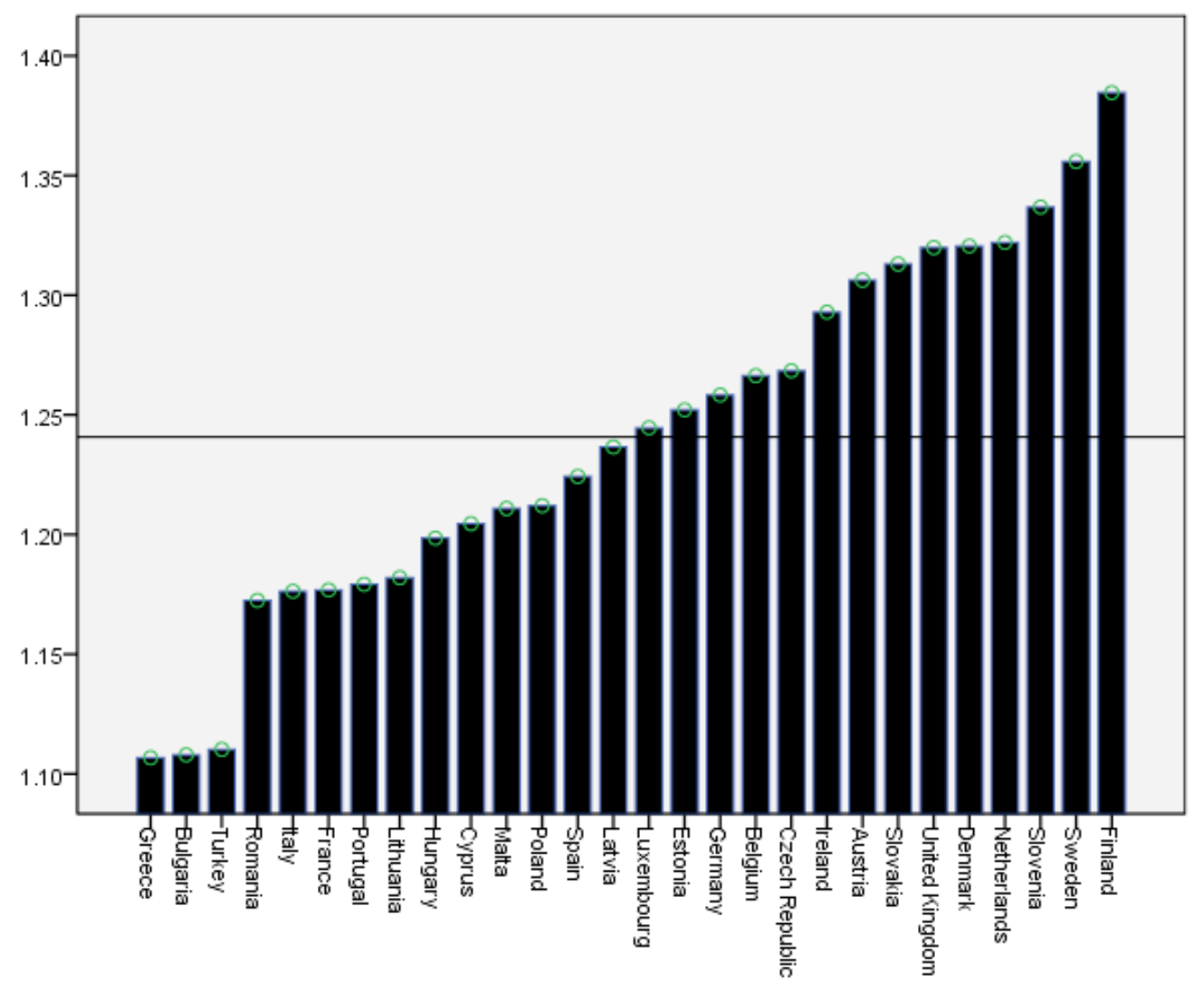

Figure 3-Amount of training to improve skills in the last 12 months.

\section{Health and Safety Risks}

The amount of preventive information taken by the employee about health and safety risks is reported highest in Ireland, United Kingdom and Cyprus. Participants from Turkey reported lowest level of training, while France and Italy reported lower levels of training for risks following Turkey. 


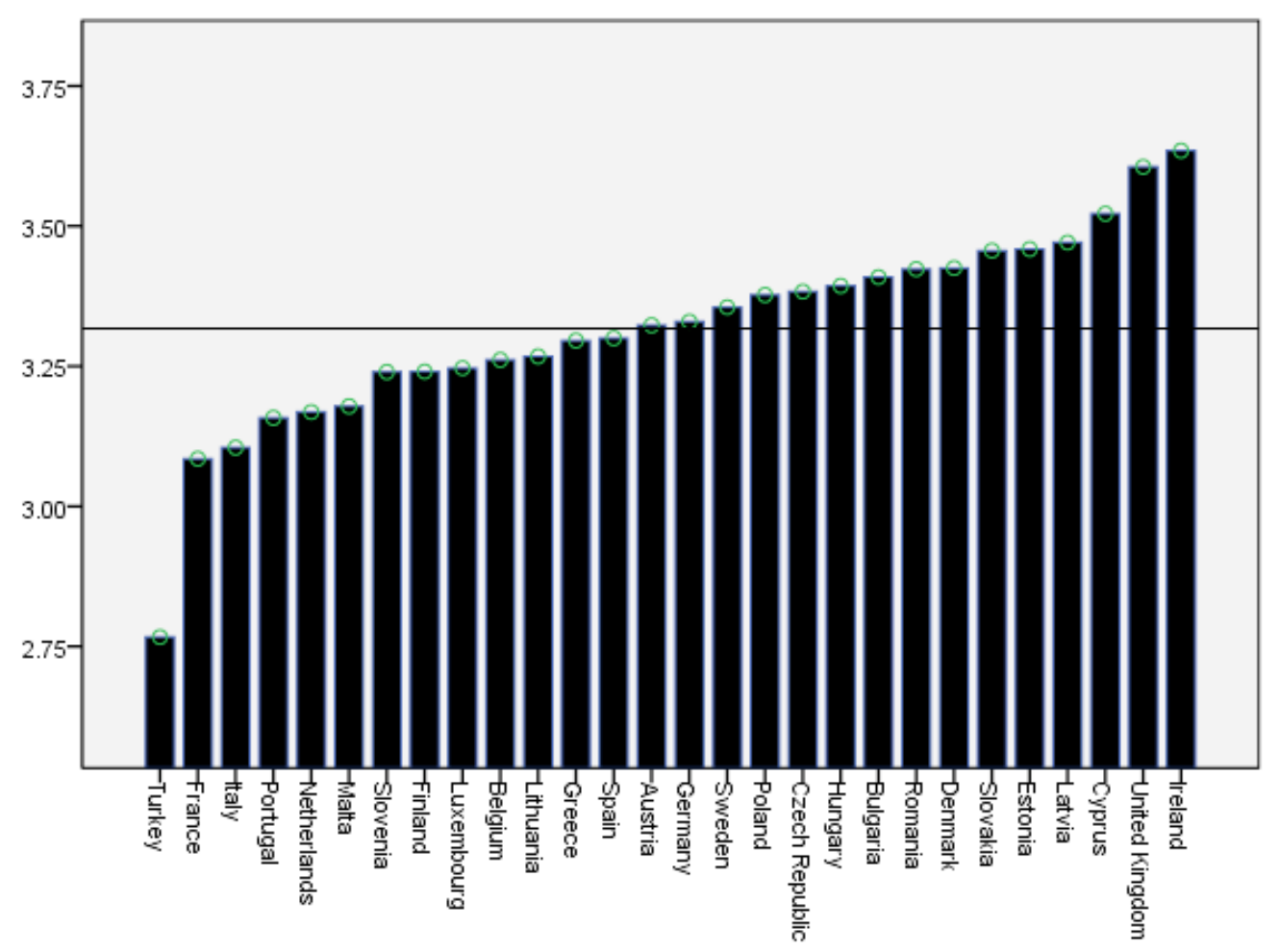

Figure 4 - Amount of information taken to prevent health and safety risks.

\section{Working Time Flexibility}

Denmark, Czech Republic and Sweden reported the most flexible working times across EU. This means the participants enjoyed flexible hours within the day, flexible days within the week, they did not work same number of hours every week and they have flexible starting and finishing times for their work. On the other hand, participants from Cyprus, Malta and Portugal have lowest levels of working time flexibility. 


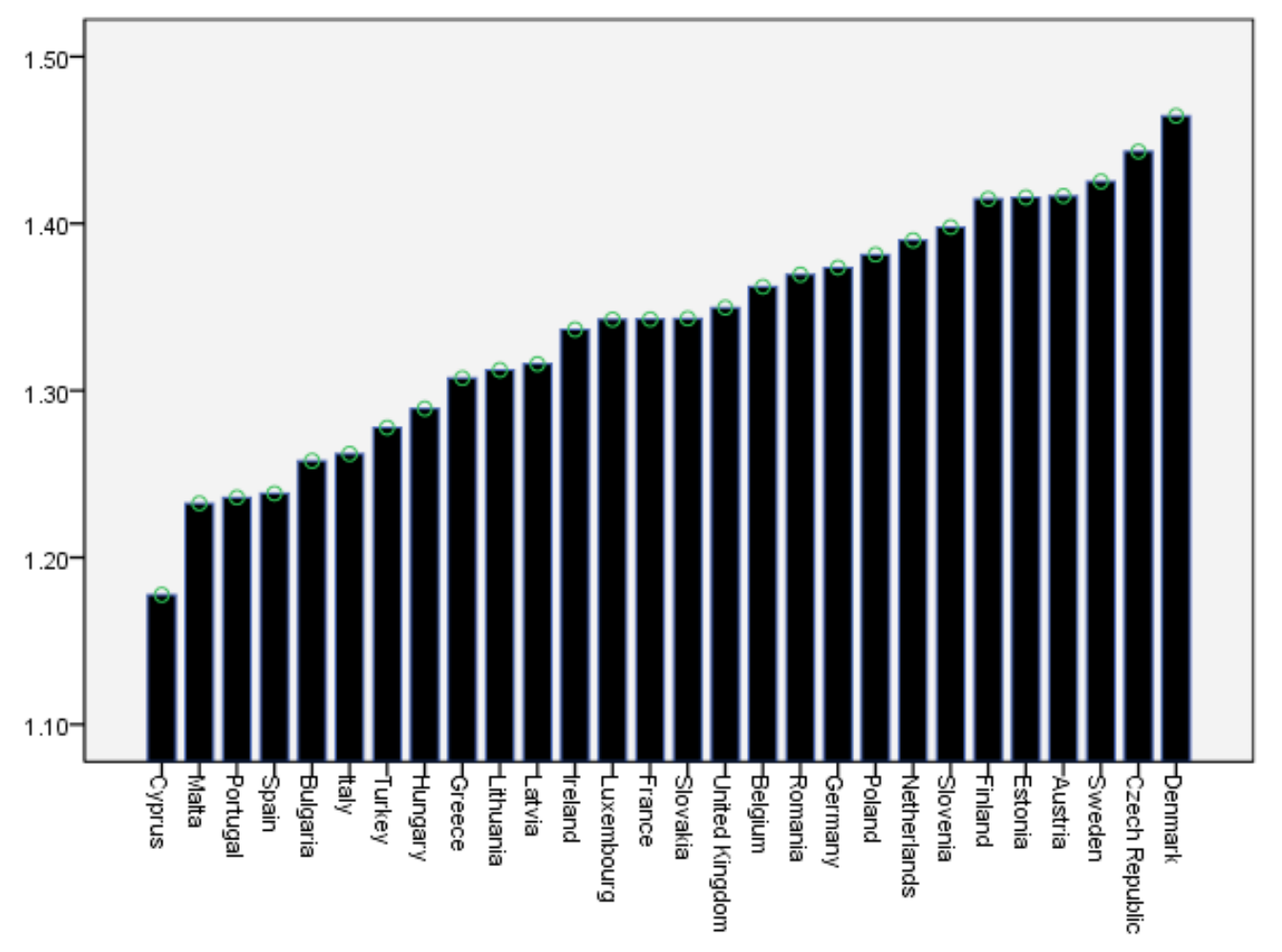

Figure 5 - Working Time Flexibility

\section{Autonomy}

Participants from Malta, Denmark and Finland reported that they have highest levels of autonomy on performing their tasks as compared to other members of the EU. Cyprus, Malta and Portugal reports low autonomy. The level of autonomy reported by Turkish participants fell below the mean value. 


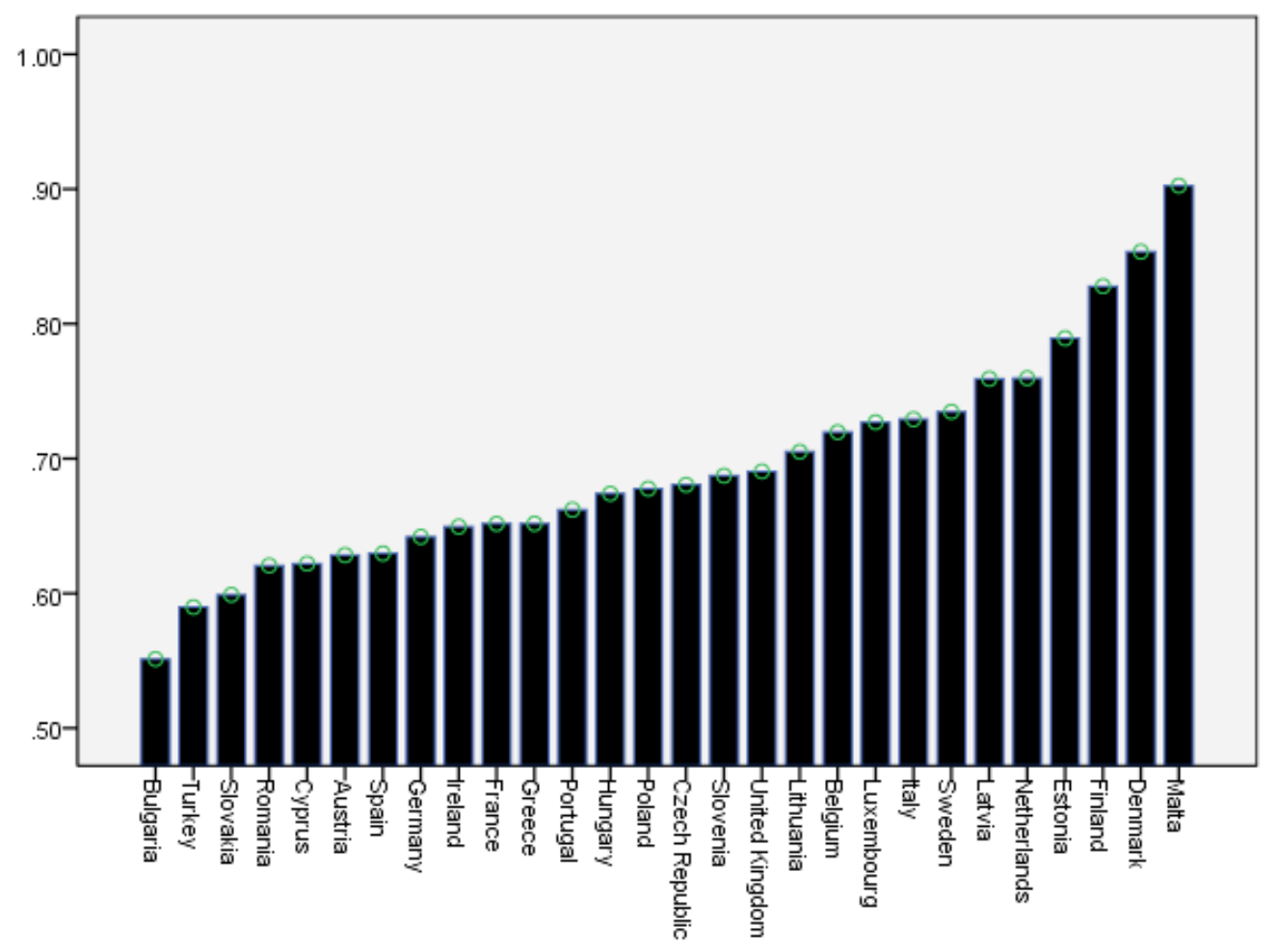

Figure 6 - Autonomy

\section{Participation}

Participation rates to workplace decisions, work related improvements and targets are measured the lowest in Slovakia, Germany and Turkey. On the other hand, participants from Estonia, Latvia and Finland reported that they have a higher say in workplace decisions as compared to others. 


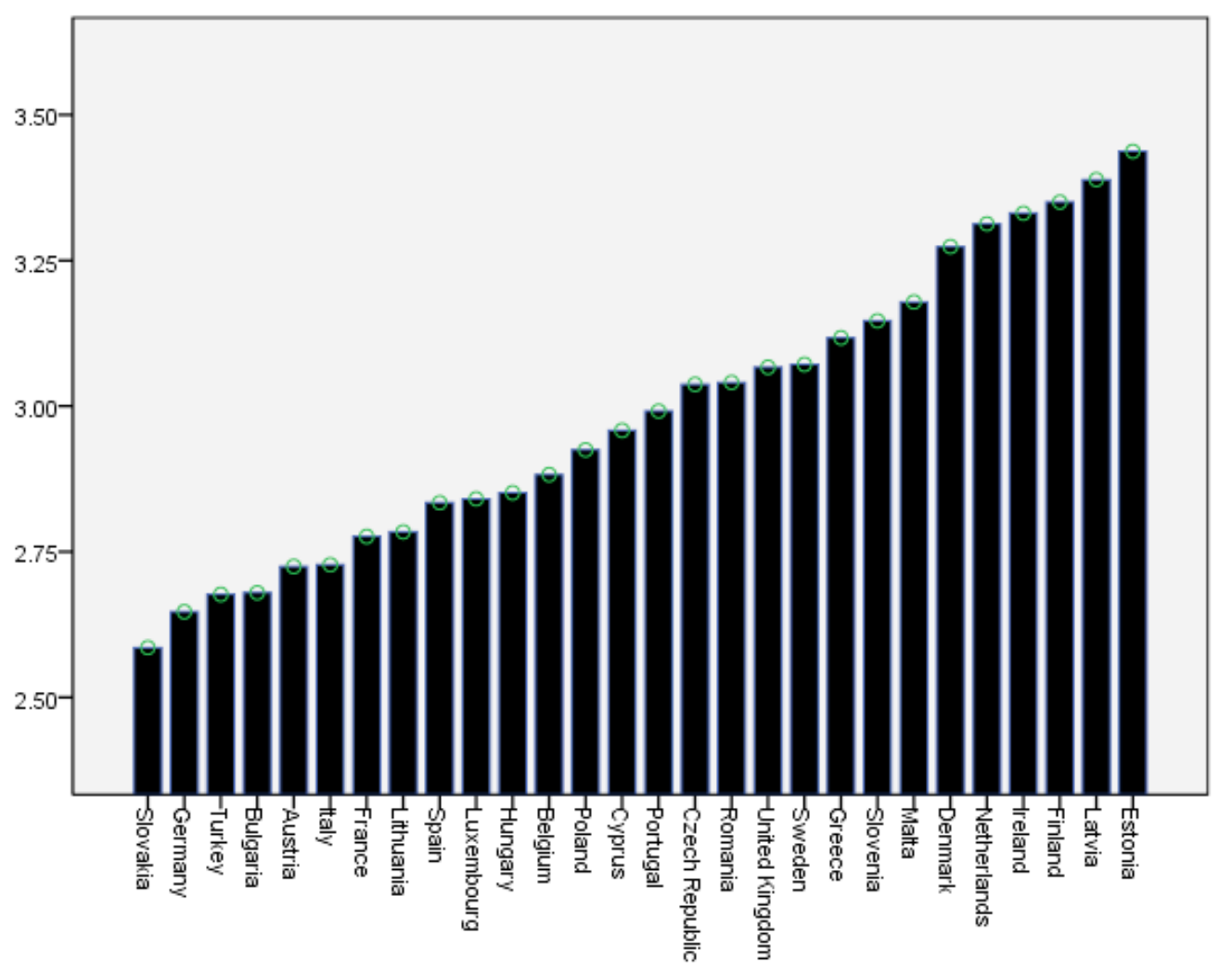

Figure 7- Participation at work.

\section{Weekly Working Hours}

Mean weekly working hours in Turkey is reported at 51 hours, and the next longest hours are reported from Greece (45 hours) and Romania (43 hours). Shortest mean weekly work hours are reported in the Netherlands (32 hours), Ireland and UK (36 hours). The mean working hours in EU 27 countries is 38 hours. 


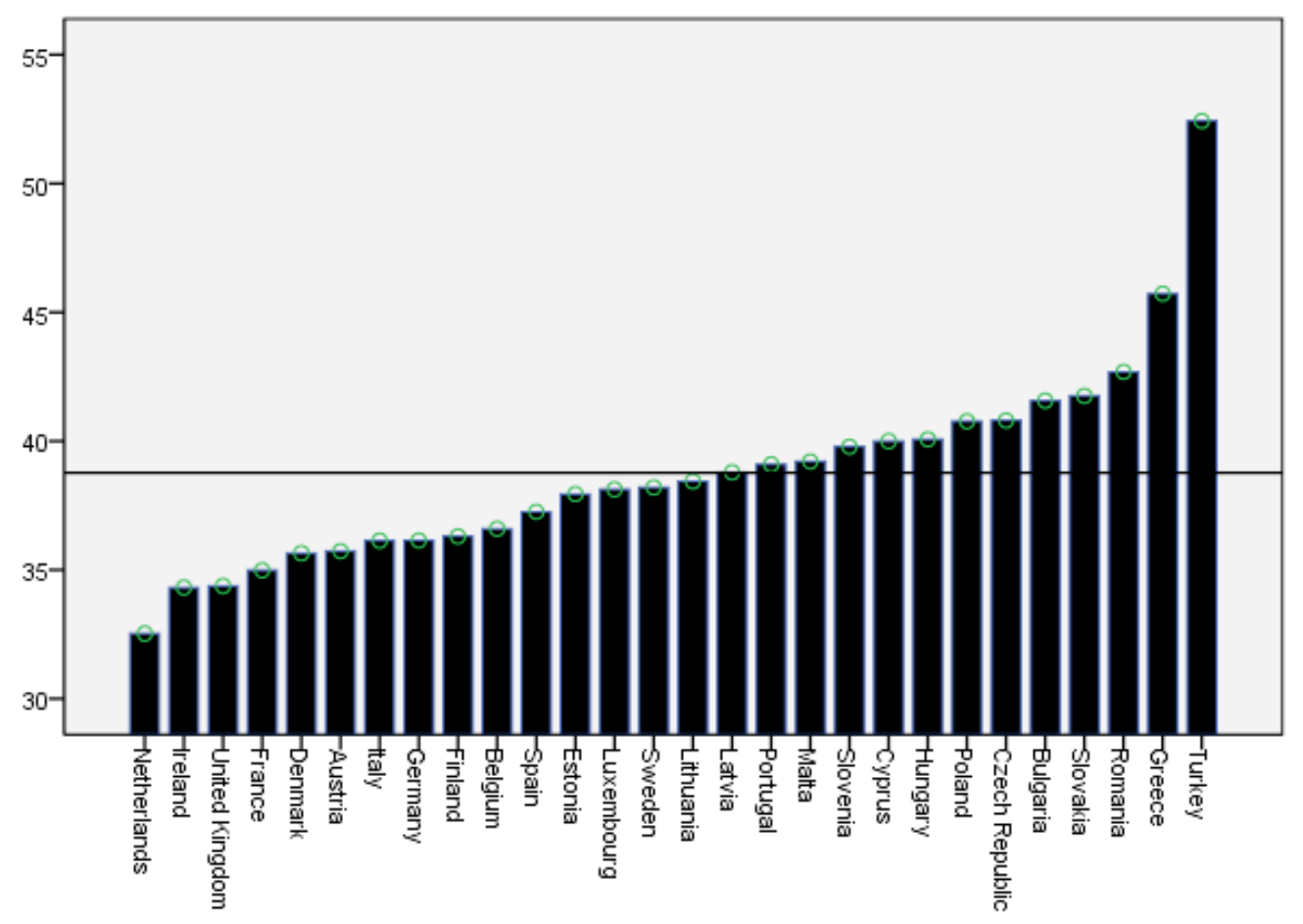

Figure 8 - Weekly working hours

Table 4 - Working days in a week

\begin{tabular}{llll}
\hline & & Frequency & Percent \\
\hline \multirow{4}{*}{ Turkey } & 1 & 7 & .3 \\
& 2 & 13 & .6 \\
& 3 & 28 & 1.3 \\
& 4 & 54 & 2.6 \\
& 5 & 495 & 23.6 \\
& 6 & 955 & 45.5 \\
EU27 & 7 & 521 & 24.8 \\
\cline { 2 - 4 } & 1 & 378 & 1.1 \\
& 2 & 824 & 2.3 \\
& 3 & 1468 & 4.2 \\
& 4 & 2412 & 6.8 \\
& 5 & 23336 & 66.0 \\
& 6 & 4829 & 13.7 \\
\hline
\end{tabular}

While respondents from the EU report that they mainly work 5 days a week, the norm in Turkey seems to be 6 days. 


\section{Discussion}

Atypical work arrangements and applications have been steadily rising in both developed and developing economies. The usual suspects are advances in production technologies, increased competition, and globalization. The numbers of people that are exposed to precarious conditions are increasing and forms of precariousness are expanding. Precariousness is becoming even more prevalent for vulnerable people in employment, thus bearing higher risks for the disadvantaged populations. Precariousness is often associated with less social protection, leaves a bleak environment for vulnerable demographics, diminishing their gains, and devastating their work-life balance.

It is worth mentioning that flexibility might bring precariousness if left unregulated. Flexible work arrangements might be seen as an outcome of current trends in the economy, but in underdeveloped economies it paves the way for arbitration and injustice, thus exacerbating resilient problems. It brings risk of crowding out decent jobs with proper pay in humane conditions.

Despite EU-27 countries, Turkey ranks relatively lower in most dimensions of precariousness, but it can be argued that Turkish economy makes up for this in other domains. A considerable strength of Turkish workers compared to EU-27 counterparts is the availability of health benefits. Although anecdotal, it is an important aspect of social protection and it helps reduce the effects of precariousness.

These results are in coherence with other quality indicators concerning work and general well-being. For instance, Turkey ranks lowest in OECD's Better Life index in work-life balance, ranks in bottom levels in job security and life satisfaction and health domains.

Precarious working conditions might be bearable for certain demographics and especially it can be tolerated in dual earner families. However, it does not change the fact that it is deleterious. Further studies should address this concern and should take gender discrimination into consideration. Another concern for precarious work is hidden unemployment; underestimated rate of employment due to a lack of fit between capabilities of the workforce and actual jobs. Agricultural jobs are convenient examples of such conditions, and most of the agricultural work is done under precarious conditions, in seasonal and temporary settings. Efforts to eradicate the precariousness factors will also help eradicate the long-term effects of an unregulated labor market.

Referring to the most current wave of EWCS 2015 would clarify the current state of precarious conditions. The most recent figures are especially important for such a vibrant workforce, and with the inclusion new workforce and immigrant workers. 


\section{References}

$5^{\text {th }}$ European Working Conditions Survey Technical Report, 2010, Gallup Europe.

Ashford, S. J., Lee, C., \& Bobko, P. (1989). Content, Cause, and Consequences of Job Insecurity: a Theory-Based Measure and Substantive Test. Academy of Management Journal, 32(4), 803-829. http://doi.org/10.2307/256569

Benach, J., \& Muntaner, C. (2007). Precarious employment and health: developing a research agenda. Journal of Epidemiology and Community Health, 61(4), 276277. http://doi.org/10.1136/jech.2005.045237

Berntson, E., Naswall, K., \& Sverke, M. (2010). The moderating role of employability on the relationship between job insecurity and commitment to change. Economic and Industrial Democracy, 31, 327-344. http://doi.org/10.1177/0143831X09351214

Berntson, E., Sverke, M., \& Marklund, S. (2006). Predicting Perceived Employability: Human Capital or Labour Market Opportunities? Economic and Industrial Democracy, 27(2), 223-244. http://doi.org/10.1177/0143831X06063098

Challenging the Market: The Struggle to Regulate Work and Income. (2004). In Stanford J., Vosko L., Stanford J., \& Vosko L. (Eds.), Challenging the Market: The Struggle to Regulate Work and Income (pp. 3-30). McGill-Queen's University Press. Retrieved from http://www.jstor.org/stable/j.ctt80j5j.4

Cranford, C. J., Vosko, L. F., \& Zukewich, N. (2003). Precarious Employment in the Canadian Labour Market: A Statistica Portrait. Just Labour, 3(Fall), 6-22.

Dekker, S. W. A., \& Schaufeli, W. B. (1995). The Effects of Job Insecurity on Psychological Health and Withdrawal: A Longitudinal Study. Australian Psychologist. http://doi.org/10.1080/00050069508259607

Forrier, A., \& Sels, L. (2003). The concept employability: a complex mosaic. International Journal of Human Resources Development and Management, 3(2), 102. http://doi.org/10.1504/IJHRDM.2003.002414

Fox, F. V., \& Staw, B. M. (1979). The trapped administrator: effects of job insecurity and policy resistance upon commitment to a course of action. Administrative Science Quarterly, 24(3), 449-471. http://doi.org/10.2307/2989922

Fugate, M., Kinicki, A. J., \& Ashforth, B. E. (2004). Employability: A psycho-social construct, its dimensions, and applications. Journal of Vocational Behavior, 
65(1), 14-38. http://doi.org/10.1016/j.jvb.2003.10.005

Gilboa, S., Shirom, A., Fried, Y., \& Cooper, C. (2008). a Meta-Analysis of Work Demand Stressors and Job Performance: Examining Main and Moderating Effects, 227-271.

Greenhalgh, L., \& Rosenblatt, Z. (1984). Job Insecurity: Toward Conceptual Clarity. Academy of Management Review, 9(3), 438-448.

Hackman, J. R., \& Oldham, G. R. (1975). Development of the Job Diagnostic Survey. Journal of Applied Psychology, 60(2), 159-170. http://doi.org/10.1037/h0076546

Hackman, J. R., \& Oldham, G. R. (1976). Motivation through the design of work: test of a theory. Organizational Behavior and Human Performance, 16(2), 250-279. http://doi.org/10.1016/0030-5073(76)90016-7

Karasek, R. a. (1979). Job Demands, Job Decision Latitude, and Mental Strain: Implications for Job Redesign. Administrative Science Quarterly, 24(2), 285308. http://doi.org/10.2307/2392498

Lazarus, R., \& Folkman, S. (1984). Stress, Appaisal and Coping. New York, NY: Springer.

Lewchuk, W., Wolff, A. de, King, A., Polanyi, M., de Wolff, A., King, A., \& Polanyi, M. (2003). From job strain to employment strain: health effects of precarious employment. Just Labour, 3, 23-35. Retrieved from http://justlabour.journals.yorku.ca/index.php/justlabour/article/view/165

Lim, V. K. G. (1996). Job Insecurity and Its Outcomes: Moderating Effects of WorkBased and Nonwork-Based Social Support. Human Relations, 49(2), 171-194. http://doi.org/10.1177/001872679604900203

Lopes, H., Lagoa, S., \& Calapez, T. (2013). Declining autonomy at work in the EU and its effect on civic behavior. Economic and Industrial Democracy, 35, 341-366. http://doi.org/10.1177/0143831X13484606

Morgeson, F., Campion, M., Garza, A., \& Campion, M. (2003). Work Design. In Handbook of psychology: Industrial and organizational psychology (Vol. 12, pp. 423-452).

Morgeson, F. P., Delaney-Klinger, K., \& Hemingway, M. a. (2005). The importance of job autonomy, cognitive ability, and job-related skill for predicting role breadth 
and job performance. The Journal of Applied Psychology, 90(2), 399-406. http://doi.org/10.1037/0021-9010.90.2.399

Orpen, C. (1993). Correlations Between Job Insecurity and Psychological Well-Being Among White and Black Employees in South Africa. Perceptual and Motor Skills, 76(3), 885-886. http://doi.org/10.2466/pms.1993.76.3.885

Roskies, E., \& Louis Guerin, C. (1990). Job insecurity in managers: Antecedents and consequences. Journal of Organizational Behavior, 11(5), 345-359. http://doi.org/10.1002/job.4030110503

Spector, P. E., Dwyer, D. J., \& Jex, S. M. (1988). Relation of job stressors to affective, health, and performance outcomes: a comparison of multiple data sources. Journal of Applied Psychology, 73, 11-19. http://doi.org/10.1037/00219010.73.1.11

Spector, P. E., \& Fox, S. (2003). Reducing subjectivity in the assessment of the job environment: development of the Factual Autonomy Scale (FAS). Journal of Organizational Behavior, 24(4), 417-432. http://doi.org/10.1002/job.199

Staufenbiel, T., \& König, C. J. (2010). A model for the effects of job insecurity on performance, turnover intention, and absenteeism. Journal of Occupational and Organizational Psychology, 83(1), 101-117. http://doi.org/10.1348/096317908X401912

The World Bank, World Development Indicators (2012). GNI per capita, Atlas method [Data file]. Retrieved from http://data.worldbank.org/ 08.05.2017.

Vandenbrande T., Vandekerckhove S., Vendramin P., Valenduc G., Huys R., Van Hootegem G., Hansez I., Vanroelen C., Puig-Barrachina V., Bosmans K., De Witte H. 2012. Quality of work and employment in Belgium. HIVA (Leuven).

Witte, H. De. (1999). Job Insecurity and Psychological Well-being: Review of the Literature and Exploration of Some Unresolved Issues. European Journal of Work \& Organizational Psychology, 8(2), 155-177. http://doi.org/10.1080/135943299398302 